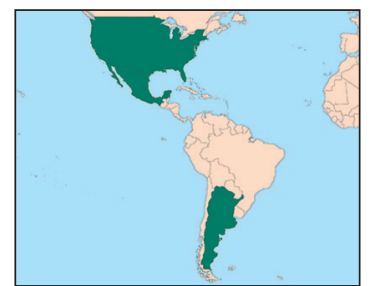

\title{
Urban water security: a comparative study of cities in the arid Americas
}

\author{
ROLANDO E DÍAZ-CARAVANTES (D), ADRIANA ZUNIGA- \\ TERAN, FACUNDO MARTÍN, MARTA BERNABEU, PHILIP \\ STOKER AND CHRISTOPHER SCOTT
}

Rolando E Díaz-Caravantes is a Professor at El Colegio de Sonora in the Center for Studies in Health and Society. Currently, his studies focus on how climate and water security risks affect or may affect vulnerable populations.

Address: El Colegio de Sonora - Center for Studies in Health and Society, Av. Obregón No. 54, Colonia Centro, Hermosillo, Sonora 83010, Mexico; email: rdiaz@colson.edu.mx; website: https://www. colson.edu.mx/RioSonora

Adriana Zuniga-Teran is a Staff Scientist at the Udall Center for Studies in Public Policy and a Senior Lecturer at the School of Landscape Architecture and Planning at the University of Arizona.

Address: email: aazuniga@ email.arizona.edu; website: https://www.researchgate. net/profile/Adriana_ZunigaTeran

Facundo Martín is a CONICET (National Scientific and Technical Research Council) researcher at the Institute for Human, Social and Environmental Sciences (INCIHUSA) and Assistant Professor in the Department of Geography at Universidad Nacional de Cuyo, Mendoza.

Address: email:

fdmartingarcia@gmail.com;
ABSTRACT In this study we analyse how three cities in the arid Americas have addressed urban growth while facing water scarcity: Hermosillo, Mexico; Mendoza, Argentina; and Tucson, USA. We use the urban water security framework to examine five domains of water management: sociodemographic, economic, technological, ecological and governance (SETEG). Our analysis indicates that, in spite of water scarcity, urban growth has been promoted in the three cities. We argue that this expansion, although encouraged for economic development, is not sustainable in the long term. In the three cities, groundwater plays a major role in water supply, but growth has negatively affected riparian ecosystems, the health of the aquifers and access to domestic water. In order to pursue water security, several options are essential to enhance social-ecological system resilience. These include limits or reduction of urban expansion, reuse of treated effluent for riparian conservation, and community conservation efforts such as rainwater harvesting and other green infrastructure.

KEYWORDS Argentina / cities / Mexico / urban growth / urban water security / USA / water management

\section{INTRODUCTION}

Urbanization is one of four global demographic megatrends (along with population growth, migration and ageing), and urban centres are projected to absorb nearly all future population growth. ${ }^{(1)}$ The Americas are the most urbanized region in the world: 82 per cent of North America's population lives in urban centres, and 81 per cent in Latin America and the Caribbean.(2) Sustainable development depends on: (1) the way urban centres grow; (2) maintenance of the linkages between rural and urban areas; and (3) the protection of the environment from the impacts of urbanization. ${ }^{(3)}$ Ensuring sustainable cities and communities is a Sustainable Development Goal (SDG 11), which aims specifically to achieve safe, resilient and inclusive cities.(4) Closely related is SDG 6, focused on provision of clean water and sanitation for all by 2030 . Although there has been significant progress in potable water supply and sanitation services, Latin America's urban residents do not always receive good-quality drinking water. There are also still serious problems associated with improved sanitation coverage in many cities. ${ }^{(5)}$ 
There are other common problems with managing urban water supplies in the Americas: 1) a general increase in groundwater and surface water pollution; 2) a lack of adequate monitoring of water quality; and 3) reduced recharge of urban aquifers due to the reduction of green cover and the expansion of impermeable infrastructure associated with urbanization. ${ }^{(6)}$

These problems are exacerbated by changes in local climatic conditions. According to Vammen,(7) many countries throughout the Americas have reported droughts that have caused serious crises in drinking water supplies, forcing authorities to ration water for irrigation and prioritize human consumption.

With all the challenges that growing cities face, it becomes even more important to analyse how they are addressing water security challenges. The purpose of this study is to examine water security in three cities in the arid Americas (Hermosillo, Mexico; Mendoza, Argentina; and Tucson, USA), and to extract lessons that can be transferred to other cities facing similar challenges. We organize this paper as follows. First, we introduce the framework for analysis. Then we describe the urban water security framework on which we base this work (Section IIa) and the geographic characteristics of the three case studies (IIb). In the Methods section (III), we outline the data sources and analyses for each of the five SETEG domains. In the Findings section (IV), we analyse the cases according to the framework. Finally, in the Conclusions section (V), we synthesise the lessons learned.

\section{BACKGROUND}

\section{a. Urban water security framework}

Scientists who study arid lands point to the need to consider these as coupled social-ecological systems. ${ }^{\left({ }^{8}\right)}$ Recognizing the importance of these joint aspects, Scott and colleagues ${ }^{(9)}$ define water security as "the sustainable availability of adequate quantities and qualities of water for resilient societies and ecosystems in the face of uncertain global change".

Relatively few academics and professionals have focused however on urban water security (UWS) at the city scale.(10) Paton and colleagues(11) studied an integrated framework for assessing water supply security in Adelaide, Australia. This included non-traditional water supply sources (desalination, wastewater reuse and rainwater harvesting). Using a simulation model for designing and testing layouts of water systems, they conclude that these technologies would be appropriate for midterm and longer-term strategies. Huang and colleagues ${ }^{(12)}$ examined a two-level assessment method that considers material and psychological security indicators related to residents in Dalian, China. This indicated that Dalian's water safety level in 2010-2012 was at the "basically secure" level.

These two studies exemplify some of the approaches to UWS; they include water supply options, spatial analysis, social perception, and so on. Other complimentary, approaches to household water insecurity and human-water sustainability, are described by Jepson and colleagues(13) and Sivapalan and colleagues.(14) Offering an approach to UWS that expands on the above-mentioned studies, Romero-Lankao and Gnatz website: https://www. researchgate.net/profile/ Facundo_Martin

Marta Bernabeu is a CONICET doctoral fellow at the Institute for Human, Social and Environmental Sciences (INCIHUSA) Mendoza, Argentina.

Address: email: mbernabeu@mendozaconicet.gob.ar

Philip Stoker is an Assistant Professor of Planning and Landscape Architecture in the College of Architecture, Planning and Landscape Architecture, University of Arizona. Philip holds a PhD in Metropolitan Planning, Policy, and Design from the University of Utah, where he completed his thesis on urban water use and sustainability.

Address: email: philipstoker@email.arizona. edu; website: https://www. researchgate.net/profile/ Philip_Stoker

Christopher A Scott is Director of the Udall Center for Studies in Public Policy, Professor in the School of Geography \& Development, and Director of the Consortium for ArizonaMexico Arid Environments, all at the University of Arizona, in Tucson, Arizona.

Address: email: cascott@ email.arizona.edu; website: https://www.linkedin.com/ in/christopher-scott-az
1. UN DESA (2019), page 46.
2. UN DESA (2018).
3. UN DESA (2018).
4. UN DESA (2019).
5. Galizia (2015).
6. Vammen (2015).
7. Vammen (2015).
8. Ostrom (2009).
9. Scott et al. (2013), page 281.
10. See for example Romero- Lankao and Gnatz (2016); Huang et al. (2015); and Paton et al. (2014).
11. Paton et al. (2014). 
12. Huang et al. (2015).

13. Jepson et al. (2017).

14. Sivapalan et al. (2014).

15. Scott et al. (2013).

16. Romero-Lankao and Gnatz (2016), page 47.
17. AguaH (2017a).

18. Romo León et al. (2014).

19. Romo León et al. (2014). propose a framework that, following Scott and colleagues, (15) defines UWS "as the capacity of urban water actors to maintain a sustainable availability of adequate quantities and quality of water, to foster resilient urban communities and ecosystems in the face of uncertain global change".(16) Their framework includes five domains: sociodemographic, economic, technological, ecological and governance (SETEG), which are described as follows:

- Sociodemographic: Fairly satisfying urban-regional water users and sanitation needs and building resilient communities and ecosystems that can sustainably adapt to change.

- Economic: Fostering vibrant urban-regional economies in industry, agriculture and energy.

- Technological: Designing and constructing (or upgrading existing) water supply and sanitation infrastructure to be multifunctional, redundant, modular (adaptable) and "safe to fail".

- Ecological: Maintaining or restoring healthy regional water bodies and ecosystems.

- Governance: Fostering water institutions that are able to balance their inherently conservative and reactive natures with the need to be adaptive, fair and flexible.

\section{b. Case studies}

In this study, we compare three cities with similar conditions of aridity and size: Hermosillo, Mexico; Mendoza, Argentina; and Tucson, USA (Map 1).

\section{Hermosillo, Sonora, Mexico}

With a total population of approximately 715,000 inhabitants in 2010, the city of Hermosillo is a vibrant urban centre that houses the political powers of the state of Sonora. The city is located in northwestern Mexico. Hermosillo receives its drinking water primarily from deep wells in just over a dozen catchment areas in the peri-urban area or within the city's boundaries (about 70 per cent). Around 30 per cent is from surface water. Of this surface water, about two-thirds is from the Yaqui River basin via the Independencia Aqueduct, and one-third from the Water Treatment Plant III, which collect water from the Abelardo L Rodríguez (ALR) and El Molinito dams. ${ }^{(17)}$

Hermosillo depends on water mainly from the Sonora River basin, because the aquifers that supply the city and the ALR and El Molinito dams are recharged from the water captured in this basin. The climate is semi-arid, average annual precipitation of the basin is 376 millimetres, and the majority of rainfall occurs during the North American monsoon season from July to September. ${ }^{(18)}$ As can be seen in Map 1, the Sonora River flows southwest, first towards the El Molinito dam, which has a storage capacity of 150 cubic hectometres, and then 23 kilometres towards ALR, which has a storage capacity of 219.5 cubic hectometres. ${ }^{(19)}$

For climate projections, experts indicate important differences between various global circulation models (GCMs) in the near and longerterm futures. As a result, water managers in the region must recognize the level of uncertainty that exists about climate change relating to the Sonora River. Perhaps more importantly, some models predict that groundwater 


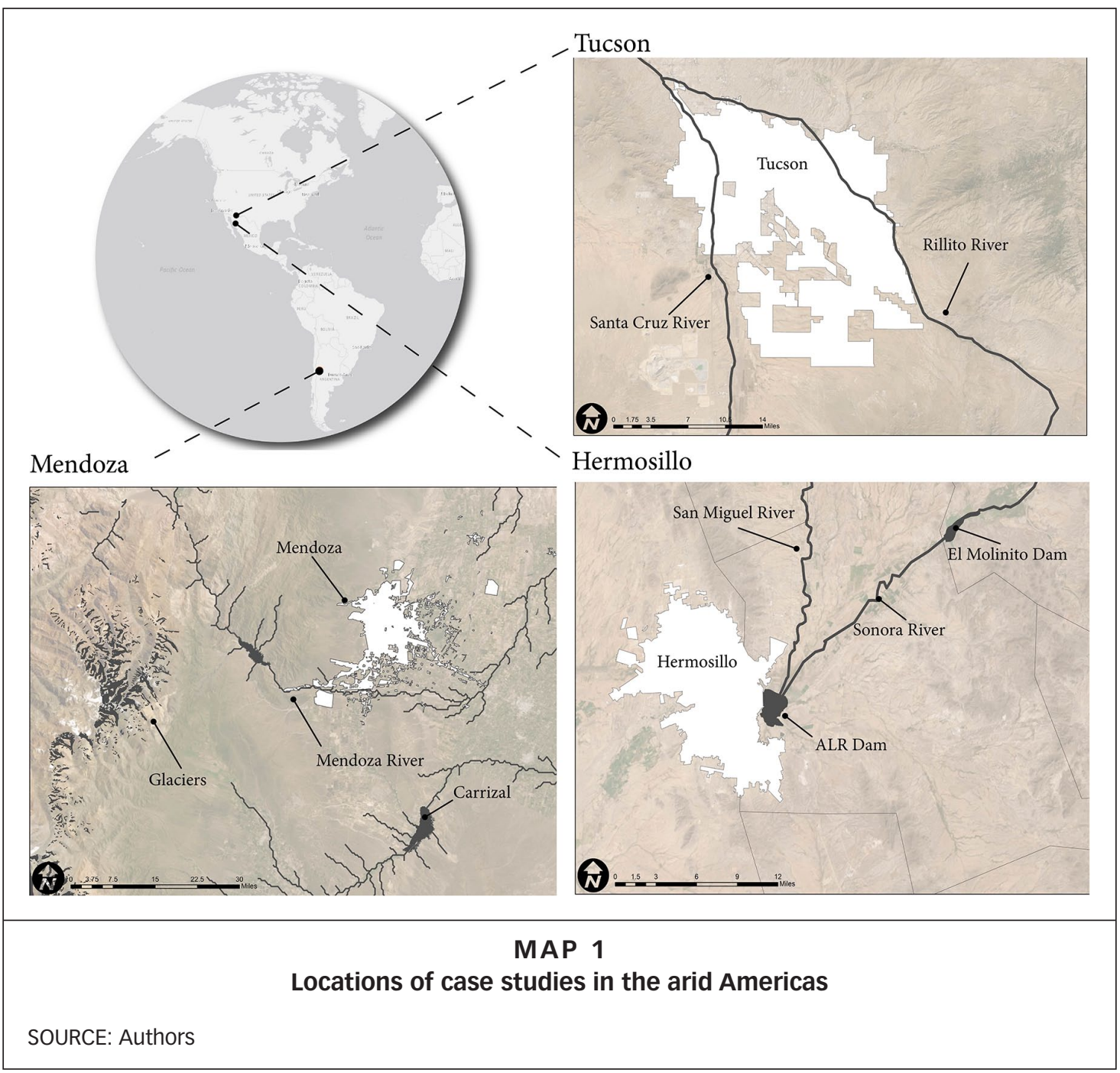

storage will decrease from the present to the future, based on predicted trends in decreasing rainfall. ${ }^{(20)}$

\section{Mendoza, Argentina}

The Mendoza Metropolitan Area (MMA), composed of seven districts, is the fifth most populous city in Argentina (with approx. 1.1 million inhabitants). It is also an economic centre for the agroindustry and financial and industrial services in the western region of the country. The MMA is bounded on the west by Chile and the Andes Mountains, and extends east to arid plains furrowed by rivers fed by mountain glaciers. The water of the Cordillera rivers are utilized through dams (Potrerillos with 450 cubic hectometres and Carrizal with 276 cubic hectometres), canals for irrigation, and water supply for the urban, industrial and more recently tourism sectors. The flow rates of both rivers and underground aquifers depend on the winter precipitation in the mountain range and extraction 
21. Leiva et al. (1989); Villalba et al. (2005); Masiokas et al. (2008).

22. Carlson et al. (2011)

23. CTWD (2004); Megdal and Forrest (2015)

24. Garfin et al. (2014).

25. Romero-Lankao and Gnatz (2016). rates from the aquifers. The regional climate is arid. Precipitation occurs in spring and summer, but the volumes received are insignificant for the development of rainfed agriculture (200 millimetres per year).

Although in these territories water deficits are structural, climate change scenarios suggest increasing aridity and an increase in the frequency and intensity of water conflicts. The increase in summer precipitation and the retreat of glaciers have a detrimental effect on the runoff of the rivers that originate in the mountains. ${ }^{(21)}$ This would affect differently the irrigated and non-irrigated territories, the urban and the rural activities, the different productive systems and, finally, the various actors involved.

\section{Tucson, Arizona, USA}

Tucson is located in southern Arizona, in a valley surrounded by mountains. The City of Tucson's population is 545,975 according to 2018 US Census Bureau estimates, with 980,263 inhabitants in Tucson's metropolitan area. The climate is semi-arid with 310 millimetres of annual precipitation distributed in two rainy seasons: the summer monsoons and the winter rains. There are two main water bodies, the ephemeral Santa Cruz River that drains from south to north and the Rillito Creek, a tributary draining from east to west. ${ }^{(22)}$

Because the rivers are generally dry, Tucson's three water sources are groundwater, water from the Colorado River, and reclaimed water. Water from the Colorado River is brought by aqueducts from hundreds of miles away and allowed to infiltrate into groundwater. The mixture of infiltrated water and groundwater is the principal water source for urban residents. However, landowners have the additional option of harvesting rainwater or using their own greywater for non-potable uses (e.g. landscape irrigation).

Limited water resources remain the greatest challenge for the water utilities in this region, ${ }^{(23)}$ particularly under drier climatic conditions. Garfin and colleagues, ${ }^{(24)}$ in their Third National Climate Assessment for the Southwest, describe future climate scenarios that include increased temperature, drought, reduced agricultural yields, and declining water supplies.

\section{METHODS}

To better understand these similarities and differences, we analyse the three cases with respect to each of the SETEG domains proposed by Romero-Lankao and Gnatz. ${ }^{(25)}$ The three cities show different governance approaches to water resources, a comparison of which allows us to compare and extract lessons that can be transferred to other cities. We base our analysis on the review of work by academic experts and water agencies to examine each of the five domains. We use 16-18 references for each case study, distributed by domain, as shown in Table 1.

\section{FINDINGS}

\section{a. Sociodemographic}

According to Romero-Lankao and Gnatz, the sociodemographic domain refers to the water and sanitation needs of urban users, and to meeting 


\section{TABLE 1}

Review of information by domain on each case study

\begin{tabular}{|c|c|c|c|c|}
\hline Domain & Topics & Hermosillo & Mendoza & Tucson \\
\hline Sociodemographic & $\begin{array}{l}\text { a) Population } \\
\text { trends } \\
\text { b) Water } \\
\text { coverage } \\
\text { c) Water quality }\end{array}$ & $\begin{array}{l}\text { CEA, 2018; AguaH, } \\
\text { 2017b; Whitten et al., } \\
\text { 2014; Vásquez-Del } \\
\text { Castillo et al., } 2013\end{array}$ & $\begin{array}{l}\text { DEIE 2016; } \\
\text { TECHO, 2016; } \\
\text { Villalba et al., } \\
2005\end{array}$ & $\begin{array}{l}\text { Tillman et al., 2016; Garfin } \\
\text { et al. 2014; PAG, n.d.; } \\
\text { Zuniga-Teran \& Staddon, } \\
2019\end{array}$ \\
\hline Technological & $\begin{array}{l}\text { a) Groundwater } \\
\text { use } \\
\text { b) Surface water } \\
\text { use }\end{array}$ & $\begin{array}{l}\text { AguaH, 2017a; } \\
\text { CONAGUA, 2013; } \\
\text { Scott \& Pineda, 2011; } \\
\text { Del Castillo, } 1994\end{array}$ & $\begin{array}{l}\text { DGI, 2016; } \\
\text { INDEC, 2010; } \\
\text { Torres et al., } \\
2003\end{array}$ & $\begin{array}{l}\text { Megdal \& Forrest, 2015; } \\
\text { Megdal et al., 2014; CTWD, } \\
\text { 2013; CTWD, } 2004\end{array}$ \\
\hline Ecological & $\begin{array}{l}\text { a) Aquifers } \\
\text { b) Riparian } \\
\text { ecosystems } \\
\text { c) Sewage }\end{array}$ & $\begin{array}{l}\text { CEA, 2018; } \\
\text { AguaH, 2017a; } \\
\text { CONAGUA, 2015; } \\
\text { Díaz-Caravantes } \\
\text { et al., 2015; Díaz- } \\
\text { Caravantes \& Wilder, } \\
\text { 2014; SEMARNAT, } \\
2001\end{array}$ & $\begin{array}{l}\text { UNICIPIO, 2018; } \\
\text { Jobbágy et al., } \\
\text { 2011; Fasciolo \& } \\
\text { Barbosa, 2010; } \\
\text { Masiokas et al., } \\
\text { 2008; Villalba } \\
\text { et al., 2005; Llop } \\
\text { \& Alvarez, 2002; } \\
\text { Leiva et al., 1989 }\end{array}$ & $\begin{array}{l}\text { Pima County, 2017; Megdal } \\
\text { \& Forrest, 2015; Kim et al., } \\
\text { 2015; Thomure \& Kmiec, } \\
\text { 2015; Scott et al., 2012; } \\
\text { ADWS, 2010; PAG, 2006; } \\
\text { CTWD, 2004; Livingston } \\
\text { et al., 2003; Al-Sabbry } \\
\text { et al., 2002; Zuniga-Teran \& } \\
\text { Staddon, } 2019\end{array}$ \\
\hline Economic & $\begin{array}{l}\text { a) Competition } \\
\text { of uses } \\
\text { b) Imported } \\
\text { water }\end{array}$ & $\begin{array}{l}\text { AguaH, 2017a; } \\
\text { Díaz-Caravantes \& } \\
\text { Wilder, 2014; Díaz- } \\
\text { Caravantes, 2012; } \\
\text { Scott \& Pineda, 2011 }\end{array}$ & $\begin{array}{l}\text { D'Inca \& Berón, } \\
\text { 2013; Rojas } \\
\text { et al., n.d. }\end{array}$ & $\begin{array}{l}\text { CTWD, 2017; Hirt et al., } \\
\text { 2017; Kirk et al., 2017; } \\
\text { Megdal et al., 2014; CTWD, } \\
\text { 2013; Zuniga-Teran \& } \\
\text { Staddon, } 2019\end{array}$ \\
\hline Governance & $\begin{array}{l}\text { a) Type of } \\
\text { institution } \\
\text { b) Adaptation } \\
\text { planning }\end{array}$ & $\begin{array}{l}\text { AguaH, 2017a; Loera } \\
\text { and Salazar, 2017; } \\
\text { Haro-Velarde et al., } \\
\text { 2016; Pineda, } 2008\end{array}$ & $\begin{array}{l}\text { EPAS 2019; } \\
\text { Bustos, } 2007\end{array}$ & $\begin{array}{l}\text { Kirk et al., 2017; Megdal } \\
\text { \& Forrest, 2015; Megdal } \\
\text { et al., 2014; CTWD, } 2013\end{array}$ \\
\hline
\end{tabular}

NOTE: The "Topics" column is based on Romero-Lankao and Gnatz (2016).

these while "building resilient communities and ecosystems that can adapt to change".(26) The three cities have grown rapidly in recent decades, and despite water scarcity, we found that the provision of potable piped water (or private wells in the Tucson case) to the urban population in the three cities is above 97 per cent.

In 1980, the total population of Hermosillo was approx. 298,000 and in $2010,716,000$, a 140 per cent increase in those 30 years. It is projected that by 2030 , the population will be around 920,000 . The coverage of the drinking water network was 97.3 per cent in 2016.(27)

In Mendoza, 65 per cent of the provincial population (approx. 1.1 million inhabitants) reside in the MMA, which experienced a 50 per cent population increase between 1980 and 2010. An increase of 25 per cent is projected for 2030 at the provincial level. The percentage of drinking water coverage is 97 per cent.(28)

In terms of water quantity, Tucson is currently water secure. With a combination of three sources (surface water from the Colorado River via the Central Arizona Project, groundwater and effluent), 100 per cent of
26. Romero-Lankao and Gnatz (2016), page 48.

27. CEA (2018).

28. INDEC (2010). 
29. Zuniga-Teran and Staddon (2019).

30. PAG (n.d.).

31. Whitten et al. (2014); Garfin et al. (2014); Villalba et al. (2005).

32. Vásquez-Del Castillo et al. (2013).

33. AguaH (2017b).

34. AguaH (2017b).

35. TECHO (2016).

36. DEIE (2016)

37. Tillman et al. (2016).

38. Tillman et al. (2016).

39. Romero-Lankao and Gnatz (2016).

40. Del Castillo (1994) the population of Tucson Metropolitan Area has potable water. ${ }^{(29)}$ The population of Tucson has grown about 75.4 per cent in the last three decades. In 1980, the population was approx. 331,000, and by 2010 had increased to $520,000 .{ }^{(30)}$ There has been marginal additional growth since then because of an economic and real estate downturn.

It is evident that populations in the three cities are expanding. To date, virtually complete water supply coverage has been achieved. However, as noted, projections include reductions of groundwater supplies in all three regions, ${ }^{(31)}$ so maintaining coverage in the future will be a big challenge.

Water quality represents an important component of the sociodemographic domain. In the case of Hermosillo, Vásquez-Del Castillo and colleagues ${ }^{(32)}$ reported that arsenic concentrations obtained from all 41 water distribution tanks in the city exceeded acceptable standards in the northern zone. According to city water agency parameters, all of the eight monitored areas reported compliance with Mexican regulations for arsenic content, an allowable limit of 0.025 milligrams per litre. (33) However, applying instead the criteria of the World Health Organization, four of the zones in the north of the city exceeded the allowable limit of 0.01 milligrams/litre. ${ }^{(34)}$

In Mendoza, 205 informal settlements occupy 0.96 per cent of the urban area and provide living space for 11,772 families. These settlements, located mainly west of the city, have a high level of environmental risk; 84.5 per cent have access to water through an irregular connection to the public network, which translates into lower quality and quantity of water. ${ }^{(35)}$ Additionally, 31.2 per cent of houses in the MMA have water supply problems (low pressure, turbidity, etc.). ${ }^{(36)}$

Within Tucson, water quality varies, mainly due to industrial activities from the 1980s, which have caused extensive groundwater contamination in the Tucson International Airport area, home mostly to low-income Hispanic families. Water extracted from this area contains elevated levels of volatile organic compounds, probably carcinogenic, and high levels of hexavalent chromium, a known human carcinogen. ${ }^{(37)}$ Even though residents of this area have access to municipal water that meet drinking water standards, a 2000 study revealed that 32 private wells remain in use, raising serious public health concerns. ${ }^{(38)}$

\section{b. Technological}

The technological domain pertains to the design and construction of water supply and sanitation infrastructure, which should be multifunctional, adaptable and safe in case of failure. ${ }^{(39)}$ In terms of water supply, in all three cases, there has been a combination of surface water and groundwater use.

In Hermosillo, groundwater has been a critical resource since the middle of the 20th century. ${ }^{(40)}$ So important has this source of water supply been that until 2012, 144 wells provided almost all the water for the city. This groundwater supply was only made possible by technological advances of water extraction. It was not until 1981 that surface water began to be used in Hermosillo, when the state government reassigned the water in the ALR dam from agriculture to municipal public services through two water treatment plants to supply the city. ${ }^{(41)}$ Another important recent 
work was the El Molinito dam, whose construction started in 1991 to prevent possible flooding in the city.

According to hydrometric information from the El Orégano station, the Sonora River has gone from a perennial flow in 1960-1995, to an ephemeral regime between 1996 and 2015.(42) The annual runoff decreased from an average of 134 cubic hectometres in the period 1960-1995 to 34 cubic hectometres in the subsequent period. During the 1996 drought, the El Molinito dam began to be used to recharge urban wells. In 2008, an aqueduct (25 kilometres) was built to use all the water from the dam, which provides 1,500 litres/second. Currently, the Molinito and ALR dam system provides only 550 litres/second of surface water. ${ }^{(43)}$ More detailed assessment of Hermosillo's "hydraulic reach" is reported by Scott and Pineda Pablos. ${ }^{(44)}$

Finally, it is worth highlighting the collection of surface water from the basin of the Yaqui River to Hermosillo through the Independencia Aqueduct. This brings water to the city from the El Novillo dam, a hydroelectric dam with a storage capacity of 2,963 cubic hectometres. In 2010, the installation of this aqueduct of approximately 145 kilometres began to transfer 75 cubic hectometres per year, which in terms of flow equals 2,375 litres/second. In 2017, this aqueduct yielded 890 litres/ second. ${ }^{(45)}$

In Mendoza, the local rivers do not have the same flow year-round, so it was necessary to build diversion dams and reservoirs to achieve better regulation and use of water resources. The diversion dikes distribute the water to irrigation areas, which are managed through gates. In the Mendoza River there are three diversion reservoirs: Cipolletti, Gustavo André and Galigniana Segura. In 2001, the Potrerillos dam (450 cubic hectometres) was built in the upper section of the Mendoza River to regulate the water supply for agricultural irrigation. ${ }^{(46)}$

In addition, about 27 per cent of Mendoza's potable water comes from groundwater sources. ${ }^{(47)}$ The economically exploitable groundwater reserves throughout the province total about 22,000 cubic hectometres, which means an average of approx. 1 cubic hectometre for each square kilometre. ${ }^{(48)}$

The biggest technical challenges regarding water security in Mendoza are in water distribution, for both human consumption and irrigation. Distribution systems are now obsolete due to low investment, and cause large water losses, which negatively affects access to drinking water for vulnerable populations located in the areas west of the city.

In Tucson, state and municipal water managers have implemented innovative technologies to increase water security (e.g. aquifer recharge, wastewater reuse, water banking - as explained below), but they have faced many challenges along the way. In the 1990s, water from the Colorado River arrived in Tucson via the Central Arizona Project (CAP) - a lined open canal, 540 kilometres long, that delivers water from the Colorado River. However, water quality issues emerged and after a period of complaints from users, Tucson's Mayor and Council mandated a return to groundwater as the only source of supply.(49)

These public water quality concerns affected policy and triggered new strategies to achieve water security. Tucson Water managers had CAP water but it was in excess of municipal demand. So Tucson Water created the Central Avra Valley Storage and Recovery Project (CAVSRP), a large recovery and recharge facility. From this facility, CAP water infiltrates
42. CONAGUA (2013).

43. AguaH (2017a).

44. Scott and Pineda Pablos (2011).

45. AguaH (2017a).

46. DGI (2016).

47. INDEC (2010).

48. Torres et al. (2003).

49. CTWD (2004); Megdal and Forrest (2015); Zuniga-Teran and Staddon (2019). 
50. CTWD (2004); Zuniga-Teran and Staddon (2019).

51. Megdal et al. (2014).

52. Romero-Lankao and Gnatz (2016).

53. CONAGUA (2015).

54. Díaz-Caravantes et al. (2015).

55. SEMARNAT (2001).

56. Leiva et al. (1989); Villalba et al. (2005); Masiokas et al. (2008).

57. Jobbágy et al. (2011), page 692.

58. Llop and Alvarez (2002) into the aquifer so that water from the river is blended with groundwater. Building on this successful approach, a second storage and recovery facility started operations in 2008. ${ }^{(50)}$ The use of surface water to recharge aquifers for future use is known as "water banking", and the Tucson initiative has served as an example throughout the world.(51)

\section{c. Ecological}

The ecological domain involves the maintenance or restoration of healthy ecosystems and water bodies. ${ }^{(52)}$ The significant dependence on groundwater in all three cases is characteristic of arid zones. A sole reliance on groundwater, however, has shown negative effects on the health of the aquifers and riparian ecosystems.

In Hermosillo, there has been overexploitation of the two main aquifers that the city largely depends on. The Costa de Hermosillo aquifer has an overexploitation of 97.62 cubic hectometres per year and Mesa del Seri-La Victoria of 45.5 cubic hectometres. These two aquifers are semiconfined (leaky aquifers) are naturally recharged mainly by the Sonora River. As in Mendoza, overexploitation is primarily related to agriculture, the main water user. However, this still has serious implications for the city, since it puts its sources at risk. Costa de Hermosillo, an irrigation district, currently has soil salinization problems and brackish groundwater. ${ }^{(53)}$

The city's use of surface water from the Sonora River has resulted in limited runoff for the riparian ecosystems in the area between the El Molinito and ALR dams, since water is released only when it is necessary to recharge the urban wells. A major change has been a decrease in agricultural water use, from 8,818 hectares in 1993 to 2,983 hectares in 2011. ${ }^{(54)}$ This change in water use could be accompanied by reforestation of the riparian area, since it has been a State Natural Protected Area since $1994,{ }^{(55)}$ but this has not happened.

As mentioned above, Mendoza has historically had water restrictions. These have become more acute in the last 10 years as a consequence of global environmental change processes. ${ }^{(56)}$ Changes in land use, resulting in greater pressure on the aquifers, were superimposed on a cycle of successive hydrological droughts, during which Mendoza River flows dropped to 50 per cent of the historical average. Mendoza's aquifers are shallow, fed mainly by Andean snow and glacier melt. ${ }^{(57)}$ There was a progressive process of salinization of aquifers in the east and north of the MMA (North Basin and Sub-basin of Carrizal Stream) that made it an unsuseable resource for irrigation. Salinity, as measured by conductivity, doubled from 2,000 to 4,000 micromhos between 1980 and 1990.(58) This is related to previous overexploitation of the aquifer and expansion of the irrigated area that collapsed in the late 1980s, from which the province has not yet recovered.

Aquifers in the Tucson Active Management Area (AMA) are alluvial and relatively deep, delimited by mountains, and filled with layers of sediment. The aquifers are replenished by natural recharge as well as artificial recharge (Colorado River water infiltrating recharge sites). The Tucson AMA contains two sub-basins - Avra Valley and Upper Santa Cruz. Increases in groundwater levels in the Avra Valley sub-basin have resulted from groundwater recharge activities, the use of CAP water 
instead of groundwater pumping, and agricultural land retirement and water transfers to the city. However, in the Upper Santa Cruz sub-basin, groundwater levels have generally decreased. ${ }^{(59)}$

The principal impact of Tucson's water practices on the region's ecological functioning was the past reliance on groundwater as the main water source. By drawing down groundwater levels, natural perennial water flows have either decreased or stopped entirely. The hydrological connection between groundwater and surface water is clear - as groundwater levels decline, there is a reduction in stream baseflow. ${ }^{(60)}$ Riparian areas and adjacent ecosystems have suffered from these reductions.(61) In addition, the drawdown in groundwater has caused ground subsidence from aquifer-system compaction, which results in damage to urban infrastructure that is costly to repair. ${ }^{(62)}$ The good news is that ground subsidence appears to have slowed down in the 2000s as a result of the aquifer recharge programmes. ${ }^{(63)}$

In terms of riparian ecosystems, the city of Tucson has demonstrated concern through urban planning efforts, ${ }^{(64)}$ which led to the awardwinning Sonoran Desert Conservation Plan for Pima County. (65) In addition to the conservation boundaries established in this plan, periurban development in Tucson is limited by natural protected areas and Native American reservations that surround the city. Despite all these boundaries and restrictions to development, urban expansion in Tucson is still possible.

In Hermosillo, 95 per cent of households were connected to a sewerage system as of 2016. ${ }^{(66)}$ That same year, the new wastewater treatment plant started operations with an installed capacity of 2,500-2,700 litres per second. And in 2017, once the sewerage system was connected, 100 per cent of wastewater was treated. ${ }^{(67)}$ Although several possibilities have been explored for the use of this wastewater (e.g. selling it for industrial use, recharging the aquifer), a good start was its use for irrigating agricultural areas in the ejidos (communal farms) of Villa de Seris and La Yesca, which had originally used groundwater that recharged from the ALR dam beginning in 1981. ${ }^{(68)}$

In MMA, according to the local water agency (Ente Provincial de Agua y Saneamiento or EPAS), sewerage coverage is generally good, with the city of Mendoza standing out with 90 per cent and adjoining Godoy Cruz with 96 per cent. Average coverage in Las Heras, Guaymallén, Maipú and Luján de Cuyo is 79 per cent, 73 per cent, 68 per cent and 63 per cent respectively. Lavalle has poor coverage at 20 per cent. ${ }^{69)}$ However, the city's rapid, disorderly expansion is increasing the total volume of wastewater and there is no current plan to manage its use. The main problem is the state of the infrastructure, given the lack of maintenance and rehabilitation. The EPAS sees the level of disinvestment as having a direct effect on the service, which is at the limit of its capacity. Wastewater continues to be sent to outdated treatment plants that are saturated and can no longer be considered functional. ${ }^{(70)}$

Tucson has 100 per cent sewer coverage through either connection to sewerage systems or on-site septic tanks, and 100 per cent of wastewater is treated. Sewerage services are provided by large publicly owned treatment plants, privately owned treatment facilities, or individual septic systems. The systems and facilities are mostly owned and operated by the Pima County Wastewater Management Department and the Town of Sahuarita.
59. ADWS (2010).

60. Killian et al. (2019).

61. CTWD (2004); Megdal et al. (2014).

62. Al-Sabbry et al. (2002).

63. Kim et al. (2015).

64. Livingston et al. (2003).

65. Pima County (2017); ZunigaTeran and Staddon (2019).

66. CEA (2018).

67. AguaH (2017a).

68. Díaz-Caravantes and Wilder (2014).

69. UNICIPIO (2018).

70. Fasciolo and Barbosa (2010). 
71. PAG (2006)

72. Scott et al. (2012); ZunigaTeran and Staddon (2019).

73. Thomure and Kmiec (2015).

74. PAG (2006)

75. Romero-Lankao and Gnatz (2016).

76. Scott and Pineda Pablos (2011).

77. Díaz-Caravantes and Wilder (2014).

78. Díaz-Caravantes (2012)

79. Moreno Vázquez (2014).

80. AguaH (2017a).

81. D'Inca and Berón (2013).

82. Rojas et al. (n.d.)
On-site septic systems are owned by property owners and it is their responsibility to maintain them.

Effluent is used in several ways in Tucson: in the irrigation of some landscapes (e.g. golf courses, parks, sports fields), management of dust from construction, cooling towers, public toilet flushing, fire suppression, spray irrigation, and riparian landscape irrigation. ${ }^{(71)}$ In addition, effluent is discharged into underground storage facilities along the Santa Cruz River, including the Sweetwater Recharge Facilities, which are used for recreation and wildlife habitats. ${ }^{(72)}$ According to Thomure and Kmiec, ${ }^{(73)}$ the golf industry in Tucson is the driving force behind the expansion of the reclaimed water. In 2003, the total volume of effluent produced by metropolitan treatment plants in Tucson was 68,061 acre-feet (approx. 84 million cubic metres). ${ }^{(74)}$

\section{d. Economic}

In the economic domain of UWS, two indicators are fundamental: competition for water and dependence on imported water. ${ }^{(75)}$

In Hermosillo, the competition is mainly between urban and agricultural uses, and the city has been the winner. ${ }^{(76)}$ But unlike in Mendoza, this competition has involved importing water, without necessarily changing land uses. According to Díaz-Caravantes and Wilder, ${ }^{(77)}$ of 13 proposed strategies involving the transfer of water from agricultural to municipal use between 1981 and 2010, nine were implemented in Hermosillo's peri-urban area. In other places, very few projects were implemented, or implementation was postponed until there were no further alternatives. In the peri-urban area, where there are about 1,000 small farmers, the water transfer to the city means many farmers have lost their water for irrigation and hence their livelihood. (78)

The Independence Aqueduct, a massive infrastructure project, transfers water from the Yaqui River via the El Novillo dam to Hermosillo, a distance of approximately 150 kilometres. One of the main groups negatively affected was the Yaqui ethnic group, which argued that if the work was finished, the drastic reduction of available water would be disastrous for them: of the 18,000 hectares they use for cultivation, only 8,000 would be available. ${ }^{(79)}$ As a protest in 2012-2015, they set up blockades of the international highway in Vícam, one of the eight Yaqui towns; however, the infrastructure work was finished and is already in use at around 30 per cent of its capacity. ${ }^{(80)}$

In Mendoza, although the most important water use is agricultural irrigation (93-97 per cent), in recent years the demand for potable water has increased to approximately 4.5 per cent of the whole. Industrial use (1.5 per cent of total requirements) is important only in the northern oasis (irrigated area) of Mendoza, where the MMA is located. ${ }^{81)}$

Because grapes are the most important agricultural crop demanding irrigation (150,000 hectares planted, 50 per cent of the total cultivated area), water development has been linked to the historically changing circumstances of viticulture. More recently, Mendoza has undergone a process of urban expansion, specifically in the transfer of surface irrigation rights with the sale of land. In 1986 within the Mendoza River basin, 6,698.64 hectares were irrigated cropland, which had changed to urban land by 2018. ${ }^{(82)}$ In fact, agricultural use has been partially 
changing (not always formally) to recreational use for irrigating parks and gardens. The farms that become urbanized frequently stop paying irrigation fees although they do not renounce their water rights. This means the defunding of canal inspections, which manage the distribution of irrigation water. In addition, the expansion of urbanization over agricultural land leaves idle much of the historic irrigation infrastructure. Urbanization also expands to the west of MMA, where there has been no such investment in infrastructure for water provision. Here, wells supply water to the population, as well as irregular connections to the public network or private cooperative tank trucks. In this area, real estate developers have the resources to access greater quantities of water, for example via the construction of aqueducts.

Economic conditions drive growth in Tucson, but this very growth may threaten future water security in the region. An anti-growth stance is not politically feasible, and so Tucson has had to maintain a fine balance between water conservation and the wise use of resources while still attracting businesses and industry. Maintaining the "oasis" condition of the city, supported entirely by groundwater and distant reservoirs, is essential to drawing new residents and businesses. The concern is that Tucson has allowed growth far beyond its water limits, particularly when considering long-term sustainability. ${ }^{(83)}$

As mentioned above, Tucson can get water via the CAP canal. However, this is not reliable because under a declared water shortage (when water levels in Lake Mead and Lake Powell drop significantly), water delivered is significantly reduced. ${ }^{(84)}$ The situation is worrisome - prolonged drought since the 2000s has reduced streamflow throughout the Colorado River basin, ${ }^{(85)}$ and it is possible that this trend will continue in the future.

Water managers have been exploring local solutions to these projected water shortages. In 2013, Tucson Water launched the Recycled Water Master Plan, which has successfully considered reclaimed water in planning for future water supply. ${ }^{(86)}$ Projections for the demand for reclaimed water show a significant increase. ${ }^{(87)}$ In addition to wastewater use, some ordinances (e.g. modifications to the plumbing codes, the Waste Water Ordinance, the Emergency Water Conservation Ordinance) have helped reduce water demand. Gradually, Tucson's landscaping preferences have shifted to less water-demanding options (xeriscaping), as supported by the Xeriscape Landscape Ordinance. ${ }^{(88)}$

\section{e. Governance}

According to Romero-Lankao and Gnatz, ${ }^{(89)}$ the governance domain for water security involves "(f)ostering water institutions able to balance their inherently conservative and reactive natures with the need to be adaptive, fair and flexible". Here, we describe briefly the water institutions in these three cities, as well as the mechanisms (and constraints) for tackling the new global and local challenges.

In Hermosillo, Agua de Hermosillo (AguaH) was created in 2002 with the function of providing and managing public services for drinking water, drainage, sewage, and the treatment and disposal of wastewater. ${ }^{(90)}$ AguaH comprises a Municipal Consultative Council, a General Director and a Government Board; the latter holds the greatest authority. ${ }^{(91)}$
83. Hirt etal. (2017).

84. Megdal etal. (2014).

85. Kirk et al. (2017).

86. Zuniga-Teran and Staddon (2019).

87. CTWD (2013).

88. CTWD (2017).

89. Romero-Lankao and Gnatz (2016), page 48.

90. Haro-Velarde et al. (2016).

91. Haro-Velarde et al. (2016). 
92. Loera and Salazar (2017).

93. Haro-Velarde etal. (2016), page 211

94. Pineda Pablos (2008)

95. AguaH (2017a).

96. Bustos (2007).

97. EPAS (2019).

98. Megdal annd Forrest (2015).

99. Megdal etal. (2014).

100. Kirk etal. (2017).
As noted by Loera and Salazar, ${ }^{(92)}$ from 2008 to 2012, AguaH faced management challenges, such as recurring deficits in its operating budget, a high dependence on federal and state contributions, and constant changes in its directive. For example, there were 14 directors between 1993 and 2017, each lasting an average of 1.7 years. ${ }^{(93)}$ This is partly because the director's appointment depends on the municipal mayor, who changes every three years. The brief duration of this strategic position has limited the management and long-term planning in AguaH. ${ }^{(94)}$ It is an obstacle to adaptive planning in a challenging context that demands this flexibility.

AguaH recently launched a long-term planning effort that promises to offer future alternatives for adequate risk management and opportunities. Among the most relevant results of this effort were robust actions on these topics: resource management for infrastructure, unpaid bills, and tariff review and autonomy of AguaH.(95)

In Mendoza, water management for irrigation is decentralized as required by the provincial constitution and the General Water Law, dating from 1884. The law establishes which lands have permanent water rights. The public body that manages the water resources in the province is the General Irrigation Department (DGI). Users, especially large property owners, participate through the cauce - or waterway - inspections that monitor the secondary irrigation network and administer its use. ${ }^{(96)}$

The regulation of water for domestic use in Mendoza is the responsibility of the Provincial Water and Sanitation Agency (EPAS). Many operators are responsible for the provision of drinking water services: the public company Aysam (the main operator, serving 64 per cent of the population), the municipalities of Maipú and Luján de Cuyo, and 142 other social entities including neighbourhood, mutual and cooperative unions. ${ }^{(97)}$

In Tucson, water management is also decentralized, governed by several institutions working in multiple jurisdictions. At the state level, water resources are governed by the Arizona Department of Water Resources, which works to manage water resources sustainably particularly groundwater - through the Assured Water Supply Program. This programme aims to prevent overpumping, mandating that all groundwater extracted in excess of incidental recharge be replenished with a renewable water supply (e.g. water from the Colorado River). However, groundwater levels have continued to decline.(98) At the federal level, water policy for the Colorado River states that Arizona has junior rights, meaning that this supply will be reduced in case of water shortage. ${ }^{\left({ }^{9}\right)}$ The situation is not optimistic. Prolonged drought since the 2000s has reduced streamflow throughout the Colorado River basin. ${ }^{(100)}$

In terms of municipal water management, Tucson Water is the largest of 10 water utility companies that provide water to the City of Tucson and its metropolitan area. It is a water utility owned and operated by the municipality, which started operations in 1900 and now services approximately 76 per cent of Tucson's population. The Metropolitan Domestic Water Improvement District is the second largest utility, serving 6 per cent, while the Town of Oro Valley serves 5 per cent. The 10 water utility companies serve different areas of the city and have specified service areas for future growth, known as "long-range planning areas". Identifying these geographical obligations helps in water resource planning. Utilities in the state of Arizona can be public or private; the 
TABLE 2

Comparison between the three cases according to the five domains

\begin{tabular}{|c|c|c|c|c|}
\hline Domains & Topics & Hermosillo & Mendoza & Tucson \\
\hline \multirow{3}{*}{$\begin{array}{l}\text { Sociodemo- } \\
\text { graphic }\end{array}$} & a) Population trends & \multicolumn{3}{|c|}{ Constant population growth } \\
\hline & b) Water coverage & \multicolumn{3}{|c|}{ Above 97 per cent in all cases } \\
\hline & c) Water quality & \multicolumn{3}{|c|}{ Significant water quality challenges have arisen in different periods } \\
\hline \multirow[t]{3}{*}{ Technological } & a) Groundwater use & \multicolumn{3}{|c|}{ High dependence on technology to exploit groundwater } \\
\hline & & $\begin{array}{l}\text { High dependence on } \\
\text { groundwater }\end{array}$ & $\begin{array}{l}\text { Medium dependence } \\
\text { on groundwater }\end{array}$ & $\begin{array}{l}\text { High dependence on } \\
\text { groundwater }\end{array}$ \\
\hline & b) Surface water use & \multicolumn{3}{|c|}{ High dependence on large human-made reservoirs } \\
\hline \multirow[t]{3}{*}{ Ecological } & a) Aquifers & $\begin{array}{l}\text { Overexploitation of } \\
\text { aquifers }\end{array}$ & $\begin{array}{l}\text { Overexploitation of } \\
\text { aquifers }\end{array}$ & $\begin{array}{l}\text { Overexploitation } \\
\text { of aquifers, but } \\
\text { started to reverse by } \\
\text { recharging the aquifer }\end{array}$ \\
\hline & $\begin{array}{l}\text { b) Riparian } \\
\text { ecosystems }\end{array}$ & $\begin{array}{l}\text { No conservation } \\
\text { strategy }\end{array}$ & $\begin{array}{l}\text { No conservation } \\
\text { strategy }\end{array}$ & $\begin{array}{l}\text { There are } \\
\text { conservation } \\
\text { strategies }\end{array}$ \\
\hline & c) Sewage & $\begin{array}{l}\text { Recently } 100 \text { per } \\
\text { cent treatment and } \\
\text { there are strategies } \\
\text { to reuse this water }\end{array}$ & $\begin{array}{l}\text { The treatment } \\
\text { plants are no longer } \\
\text { functional }\end{array}$ & $\begin{array}{l}\text { Treated wastewater } \\
\text { is used for multiple } \\
\text { uses, including } \\
\text { aquifer recharge }\end{array}$ \\
\hline \multirow[t]{2}{*}{ Economic } & $\begin{array}{l}\text { a) Competition of } \\
\text { uses }\end{array}$ & \multicolumn{3}{|c|}{$\begin{array}{l}\text { The main competition is between agricultural and city consumption } \\
\text { uses }\end{array}$} \\
\hline & b) Imported water & $\begin{array}{l}\text { Inter-basin imported } \\
\text { water }\end{array}$ & Not imported water & $\begin{array}{l}\text { Inter-basin imported } \\
\text { water }\end{array}$ \\
\hline \multirow[t]{2}{*}{ Governance } & a) Type of institution & Decentralized & Decentralized & Decentralized \\
\hline & $\begin{array}{l}\text { b) Adaptation } \\
\text { planning }\end{array}$ & Short-term planning & Short-term planning & Long-term planning \\
\hline
\end{tabular}

former are regulated by elected municipal government and the latter by the Arizona Corporation Commission. (101) $^{2}$

The "long-range planning areas" cover all of the City of Tucson and portions of unincorporated Pima County adjacent to the city boundaries. Any development and water provision outside this area requires the approval of the Tucson Mayor and Council.(102) The main water utility company, Tucson Water, developed a strategic plan in 2012 to meet future water demand and serve a growing population.

Table 2 compares UWS in the three case study cities. We can see that the challenges to achieving water security are significant. The population will continue to increase in all three cities. Although all three have managed to cover all or most of the water demand, the quantity and quality of water are emerging as current and future challenges.

In the technological domain, our three cases show a dependence on groundwater, not only as an alternative water source, but, in the case of Hermosillo and Tucson, as the main source of water supply. Dependence on groundwater is risky due to overexploitation of aquifers and consequent problems with salinity, observed in all three cases. However, this trend has begun to reverse in the case of Tucson, as a result of its transfer of water from the Colorado River and use of treated wastewater for ecological uses.
101. City of Tucson (n.d.).

102. CTWD (2013). 
103. Gleick (2003), page 1524.

104. Brooks and Brandes (2011); Gleick (2003); Scott and Lutz-Ley (2016).
Mendoza cannot rely on this option because its treatment plant is not functional. Meanwhile, Hermosillo has an emerging opportunity to use effluent for aquifer recharge or ecological uses like Tucson, because it is now treating all its wastewater. This effluent could potentially be used for the recovery of riparian ecosystems, or other non-potable uses.

As observed in the economic domain, cities' biggest water competitor is agriculture, a reflection of the regional economic history of these cities, which was basically agricultural. The winner of this competition has turned out to be urban residential use, although the resources surrounding the city have not been sufficient to cover demand. There is a dependence on inter-basin imported water, and from a great distance in Hermosillo and Tucson. Although this dependence is common in large modern cities, it represents a great challenge in the context of diminishing water supplies related to climate change. We found this emerging threat in all three cases: a decrease in snowmelt and water in the Colorado River for Tucson, in the Andes Mountains for Mendoza, and in the Yaqui River for Hermosillo.

When the technological and economic domains are analysed, it is clear that the water projects in these three cities were based on a "hard path" approach, or "the construction of massive infrastructure in the form of dams, aqueducts, pipelines, and complex centralized treatment plants".(103) According to scholars, what is required in this new century are "soft path" approaches, ${ }^{(104)}$ which focus less on increasing supply and more on reducing water use through innovation, conservation and changes in use patterns.

Several lessons can be learned from the governance analysis of these three cities. The form of governance varies, with different impacts on their multiple shared problems. Tucson is the most successful case in terms of medium- and long-term planning. The autonomy and diversity of the relevant agencies have allowed them to implement innovative ideas for water management. The case of Mendoza is paradoxical in this sense; although it has a good degree of autonomy, the legislative rigidity that has emerged since the 19th century does not allow sufficient flexibility to face current water security challenges. In addition, there has been practically no investment in infrastructure and technology. Hermosillo is very different from the others in terms of autonomy. Although it has had its own water agency since 2002, it depends heavily on federal and state resources, and its management is subject to political changes. This situation is inherited from many years of centralized federal government.

\section{CONCLUSIONS}

We extract several lessons from this analysis that could be transferred to other growing cities struggling with water scarcity. Groundwater plays a critical role in UWS in cities in arid lands, but it must be managed sustainably to avoid aquifer depletion and pollution. Groundwater management has to include a recharge scheme to avoid depletion. Maintaining the health of aquifers is a priority for achieving UWS. Periurban areas in arid lands are places of flux where urbanization expands (or contracts), and water use usually shifts from agricultural to municipal. These conditions can result in the increased vulnerability of certain 
populations, usually underserved communities. Water managers should focus on protecting these vulnerable communities.

Hard path approaches to water management in growing cities in arid lands are a necessary but insufficient condition to assure water supply. Our cases point to the common use of inter-basin transfers, recharge facilities and dams, among other approaches. However, these hard path approaches have to be combined with soft path approaches that reduce demand and increase efficiency. A key soft path strategy lies in enhancing the role and effectiveness of institutions, which should be strengthened to support water governance, including stakeholder participation in decision-making. Decentralization of water management also shows promise in addressing local issues more efficiently.

In arid lands, riparian areas provide multiple critical ecosystem services, and allocation of water resources must reflect this. It is also important to consider the integrated aspect of water resources and how groundwater extraction affects riparian ecosystems. The use of effluent from wastewater treatment plants shows promise as an ecological practice. There is often a tension in urban areas between economic development (urban expansion) and the conservation of resources. Cities in arid lands may simply not be able to grow indefinitely, and it is important to establish sustainability thresholds for population growth. Sustainable growth has to be accompanied by land-use planning that protects ecosystem functions. This points again to the necessity for responsive and effective institutions.

The analysis of UWS in these three cases makes it clear that it is easier to speak in terms of water insecurity than water security. There are multiple threats to achieving a secure supply: among them meteorological and hydrological droughts, altered ecosystems, high water demand due to constant population growth, overexploited water bodies, and obsolete infrastructure. Given this diversity of problems, the clearest option in terms of governance is to emphasize the maintenance of social-ecological systems. Initiatives like the use of treated wastewater illustrate robust actions and sustainable alternatives that cities should plan regardless of their future scenario.

In summary, this study examined UWS in three cities of the arid Americas, using the domains proposed by Romero-Lankao and Gnatz. ${ }^{(105)}$ This framework proved useful for assessing water (in)security because it provides concrete dimensions and indicators that show the challenges and opportunities for achieving an adequate water supply, in terms of both quantity and quality, for cities and their regions. And however convenient it is to consider the five separate domains, clearly they are not isolated, but interweave and interact with each other. According to Romero-Lankao and Gnatz,(106)"attention to their interactions, tradeoffs and synergies will be necessary to create true UWS". Future research should consider notions from political ecology for a more detailed analysis of the winners and losers of water management decisions - an analysis that is critical for the design and implementation of new water policies.

\section{FUNDING}

The author disclosed receipt of the following financial support for the research, authorship, and/or publication of this article: Partial funding
105. Romero-Lankao and Gnatz (2016).

106. Romero-Lankao and Gnatz (2016), page 50. 
for this research was provided by the Inter-American Institute for Global Change Research CRN3056 Project (supported by NSF Grant No. GEO1128040). We further acknowledge the Lloyd's Register Foundation, a charitable foundation helping protect life and property by supporting engineering-related education, public engagement and the application of research, and NSF Grant No. DEB-1010495.

\section{ORCID ID}

Rolando E Díaz-Caravantes (iD https://orcid.org/0000-0002-4117-2197

\section{REFERENCES}

ADWS (2010), Arizona Water Atlas, Volume 8, Active Management Area Planning Area, Arizona Department of Water Resources, accessed 27 January 2020 at https://www.resolutionmineeis. us/documents/adwr-arizona-water-atlasvol-8-2010.

AguaH (2017a), Enfoque de Planeación por Escenarios para el Reforzamiento de las Capacidades Adaptativas del Organismo Operador de Agua de Hermosillo, Agua de Hermosillo.

AguaH (2017b), Agua de Calidad, Agua de Hermosillo, accessed 15 August 2018 at http:// aguadehermosillo.gob.mx/aguah/calidad-delagua

Al-Sabbry, M M, D Harris and R Fox (2002), “An economic assessment of ground water recharge in the Tucson Basin", JAWRA: Journal of the American Water Resources Association Vol 38, No 1, pages 119-131.

Brooks, D B and O M Brandes (2011), "Why a water soft path, why now and what then?", International Journal of Water Resources Development Vol 27, No 2, pages 315-344.

Bustos, R (2007), Conflicto Social y Uso del Agua: Redes Sociales e Identidades en la Resignificación del Proceso de Descentralización en la Distribución del Agua, Informe de Investigación Proyecto SeCTyPUNCuyo.

Carlson, M A, K A Lohse, J C McIntosh and J E McLain (2011), "Impacts of urbanization on groundwater quality and recharge in a semi-arid alluvial basin", Journal of Hydrology Vol 409, Nos 1-2, pages 196-211.

CEA (2018), Sistema de Indicadores, Comisión Estatal del Agua.

City of Tucson (n.d.), Public and Private Utilities.

CONAGUA (2013), Programa Detallado de Acciones de Gestión Integral para la Restauración Ecológica del Río Sonora, Comisión Nacional del Agua, accessed
15 August 2018 at http://www.ciad.mx/archivos/ Programa_Detallado_Acciones_Rio_Sonora.pdf.

CONAGUA (2015), Estadísticas del Agua en México, Comisión Nacional del Agua, accessed 22 August 2018 at http://www.conagua.gob.mx/ CONAGUA07/Publicaciones/Publicaciones/ EAM2015.pdf.

CTWD (2004), Water Plan: 2000-2050, City of Tucson Water Department.

CTWD (2013), 2012 Update Water Plan: 2000-2050, City of Tucson Water Department.

CTWD (2017), Xeriscape Landscaping and Screening Regulations- Ordinance 7522, City of Tucson Water Department.

D'Inca, V and N Berón (2013), “Expansión urbana de ciudades intermedias: modelos de desarrollo y legislación: reflexión a partir del caso del Gran Mendoza, Argentina", Geo UERJ Vol 24, No 1, pages 256-284.

DEIE (2016), Encuesta de Condiciones de Vida, Dirección de Estadísticas e Investigaciones Económicas, Gobierno de Mendoza.

Del Castillo, J M (1994), "Protección y restauración ecológica-ambiental de la Presa Abelardo Rodríguez Luján, en Hermosillo, Sonora", Estudios Sociales Vol V, No 9, pages 65-102.

DGI (2016), Aquabook: Volumen de Embalses, Departamento General de Irrigación, accessed 28 August 2019 at http://aquabook.agua.gob.ar/476_0.

Díaz-Caravantes, R E (2012), "Balancing urban and peri-urban exchange: water geography of rural livelihoods in Mexico", The Geographical Journal Vol 78, No 1, pages 42-53.

Díaz-Caravantes, R E, J R Romo-León, C A Scott and R Méndez (2015), "Riesgo a la seguridad hídrica de los ecosistemas del Río Sonora por el manejo de la presa El Molinito", paper presented at the V Congreso Mexicano de Ecología, San Luis Potosí, 20-22 April. 
Díaz-Caravantes, R E and M Wilder (2014), "Water, cities and peri-urban communities: geographies of power in the context of drought in Northwest Mexico", Water Alternatives Vol 7, No 3, pages 499-517.

EPAS (2019), Ente Provincial del Agua y Saneamiento, accessed 5 September 2019 at http://www.epas. mendoza.gov.ar/index.php/institucional.

Fasciolo, G and C Barbosa (2010), Auditoría General Obras Sanitarias MendozaS.A.:Aspectos Ambientales, informe de auditoría externa, Organización y cobertura del servicio de tratamiento y reuso de efluentes cloacales, Instituto de Ciencias Ambientales de Mendoza.

Galizia, J (2015), "Waters in urban regions", in Urban Water Challenges in the Americas: A Perspective from the Academies of Sciences, Inter-American Network of Academies of Sciences (IANAS) and United Nations Educational, Scientific and Cultural Organization (UNESCO), Paris and Montevideo, page 19.

Garfin, G, G Franco, H Blanco, A Comrie, P Gonzalez, T Piechota, R Smyth and R Waskom (2014), "Southwest", in J M Melillo, T C Richmong and G W Yohe (editors), Climate Change Impacts in the United States: The Third National Climate Assessment, US Global Change Research Program, pages 462-486.

Gleick, P H (2003), "Global freshwater resources: softpath solution for the $21^{\text {st }}$ century", Science Vol 302, pages 1524-1528.

Haro-Velarde, N, J L Moreno Vázquez and E LoeraBurnes (2016), "Batallando en el desierto: ineficiencia y conflictos por el manejo del agua potable en Hermosillo", in A Salazar-Adams (editor), Fugas de Agua y Dinero: Factores PolíticosInstitucionales que Inciden en el Desempeño de los Organismos Operadores de Agua Potable en México, El Colegio de Sonora, Hermosillo, pages 197236.

Hirt, P, R Snyder, C Hester and K Larson (2017), “Water consumption and sustainability in Arizona: a tale of two desert cities", Journal of the Southwest Vol 59, Nos 1-2, pages 264-301.

Huang, Y, L Xu, H Yin, Y Cai and Z Yang (2015), “Dual level material and psychological assessment of urban water security in a water-stressed coastal city", Sustainability Vol 7, No 4, pages 3900-3918.

INDEC (2010), Censo 2010, Instituto Nacional de Estadística y Censos de la República Argentina, accessed 3 July 2018 at http://www.indec.gob.ar.

Jepson, W, J Budds, L Eichelberger, L Harris, E Norman, K O'Reilly, A Pearson, S Shah, J Shinn, C Staddon, J Stoler, A Wutich and S Young (2017), “Advancing human capabilities for water security: a relational approach", Water Security Vol 1, pages 46-52.

Jobbágy, E G, M D Nosetto, P E Villagra and R B Jackson (2011), "Water subsidies from mountains to deserts: their role in sustaining groundwaterfed oases in a sandy landscape", Ecological Applications Vol 21, No 3, pages 678-694.

Killian, C D, W H Asquith, J R B Barlow, G C Bent, W H Kress, P M Barlow and D W Schmitz (2019), "Characterizing groundwater and surface-water interaction using hydrographseparation techniques and groundwater-level data throughout the Mississippi Delta, USA", Hydrogeology Journal Vol 27, No 6, pages 21672179.

Kim, J W, Z Lu, Y Jia and C K Shum (2015), “Ground subsidence in Tucson, Arizona, monitored by time-series analysis using multi-sensor InSAR datasets from 1993 to 2011", ISPRS Journal of Photogrammetry and Remote Sensing Vol 107, pages 126-141.

Kirk, J P, S C Sheridan and T W Schmidlin (2017), "Synoptic climatology of the early $21^{\text {st }}$ century drought in the Colorado River Basin and relationships to reservoir water levels", International Journal of Climatology Vol 37, No 5, pages 2424-2437.

Leiva, J C, L E Lenzano, G A Cabrera and J A Suarez (1989), "Variations of Rio Plomo Glaciers, Andes Centrales Argentinos", in J Oerlemans (editor), Glacier Fluctuations and Climatic Change, Springer Netherlands, pages 143-151.

Livingston, M, W W Shaw and L K Harris (2003), “A model for assessing wildlife habitats in urban landscapes of eastern Pima County, Arizona (USA)", Landscape and Urban Planning Vol 64, No 3, pages 131-144.

Llop, A and A Alvarez (2002), Guía sobre Salinización del Agua Subterránea en el Este Mendocino, Instituto Nacional del Agua, Mendoza.

Loera, E and A Salazar (2017), "Gestión de recursos humanos en organismos de agua de Hermosillo y Mexicali", Estudios Fronterizos Vol 18, No 36, pages $25-53$.

Masiokas, M H, R Villalba, B H Luckman, M E Lascano, S Delgado and P Stepanek (2008), "20th-century glacier recession and regional hydroclimatic changes in northwestern Patagonia", Global and Planetary Change Vol 60, No 1, pages 85-100.

Megdal, S B, P Dillon and K Seasholes (2014), "Water banks: using managed aquifer recharge to meet water policy objectives", Water Vol 6, No 6, pages 1500-1514.

Megdal, S B and A Forrest (2015), "How a droughtresilient water delivery system rose out of the desert: the case of Tucson water", Journal AWWA Vol 107, No 9, pages 46-52.

Moreno Vázquez, J L (2014), Despojo de Agua en la Cuenca del Río Yaqui, Hermosillo, Sonora, El Colegio de Sonora, 339 pages.

PAG (2006), 208 Plan: Areawide Water Quality Management Plan, Pima Association of 
Governments, accessed 15 June 2018 at http:// www.pagregion.com/documents/Water/ PC208/208PlanUpdate_Apr06.pdf.

PAG (n.d.), Demographics: Pima Association of Governments, accessed 12 December 2019 at https://www.pagregion.com/RegionalData/ Demographics/tabid/104/Default.aspx.

Paton, F L, G C Dandy and H R Maier (2014), "Integrated framework for assessing urban water supply security of systems with non-traditional sources under climate change", Environmental Modelling \& Software Vol 60, Issue C, pages 302-319.

Pima County (2017), The Sonoran Desert Conservation Plan, accessed 22 November 2019 at https:// webcms.pima.gov/government/sustainability_ and_conservation/conservation_science/the _ sonoran_desert_conservation_plan.

Pineda Pablos, N (2008), "Nacidos para perder dinero y derrochar agua: el inadecuado marco institucional de los organismos operadores de agua en México", in D Soares, S Vargas and M R Nuño (editors), La Gestión de los Recursos Hidráulicos: Realidades $y$ Perspectiva, Tomo I, Instituto Mexicano de Tecnología del Agua-Universidad de Guadalajara, Guadalajara, pages 121-150.

Rojas, F, M C Rubio, M Rizzo, F Martin, M Bernabeu and N Akil (n.d.), "Land use and land cover in irrigated drylands: a long-term analysis of changes in the Mendoza and Tunuyán River basins, Argentina (1986-2018)", in review, Applied Spatial Analysis and Policy.

Romero-Lankao, P and D M Gnatz (2016), "Conceptualizing urban water security in an urbanizing world", Current Opinion in Environmental Sustainability Vol 21, pages 45-51.

Romo León, J R, A Castellanos and R Méndez (2014), Programa de medidas preventivas y de mitigación de la Sequía, Consejo de Cuenca Alto Noroeste, México DF, Comisión Nacional del Agua, accessed 13 December 2019 at https://www.gob.mx/cms/ uploads/attachment/file/99913/PMPMS_CC_ Alto_Noroeste_R.pdf.

Scott, C A, C J Bailey, R P Marra, G J Woods, KJ Ormerod and K Lansey (2012), "Scenario planning to address critical uncertainties for robust and resilient waterwastewater infrastructures under conditions of water scarcity and rapid development", Water Vol 4 , pages $848-868$.

Scott, C A and A N Lutz-Ley (2016), "Enhancing water governance for climate resilience: Arizona, USASonora, Mexico comparative assessment of the role of reservoirs in adaptive management for water security", in C Tortajada (editor), Increasing Resilience to Climate Variability and Change: The Roles of Infrastructure and Governance in the Context of Adaptation, Springer, Berlin, pages 15-40.
Scott, C A, F J Meza, R G Varady, H Tiessen, J McEvoy, G M Garfin, M Wilder, L M Farfán, N Pineda and E Montaña (2013), "Water security and adaptive management in the arid Americas", Annals of the Association of American Geographers Vol 103, No 2, pages 280-289.

Scott, C A and N Pineda Pablos (2011), "Innovating resource regimes: water, wastewater, and the institutional dynamics of urban hydraulic reach in northwest Mexico", Geoforum Vol 42, No 4, pages 439-450.

SEMARNAT (2001), Áreas Naturales Protegidas de México con Decretos Estatales, Secretaría del Medio Ambiente y Recursos Naturales, Instituto Nacional de Ecología y Comisión Nacional de Áreas Naturales Protegidas, accessed 23 May 2018 at http://centro.paot.org.mx/documentos/ine/ areas_naturales_vol.2.pdf.

Sivapalan, M, M Konar, V Srinivasan, A Chhatre, A Wutich, C A Scott, J L Wescoat and I RodríguezIturbe (2014), "Socio-hydrology: use-inspired water sustainability science for the Anthropocene", Earth's Future Vol 2, No 4, pages 1-6.

TECHO (2016), Relevamiento de Asentamientos Informales, accessed 5 March 2018 at http:// relevamiento.techo.org.ar/index.html.

Thomure, T and J Kmiec (2015), The Importance of the Tucson Water Regional Reclaimed Water System to the Economic Vitality of the City of Tucson - Pima County Region, accessed 15 November 2018 at https:// watereuse.org/wp-content/uploads/2015/01/ Importance_Tucson.pdf.

Tillman, F D, R B McCleskey and E Hermosillo (2016), "Investigation of total and hexavalent chromium in filtered and unfiltered groundwater samples at the Tucson International Airport Superfund site", Bulletin of Environmental Contamination and Toxicology Vol 97 No 4, pages 543-547.

Torres, E, E M Abraham, E Montaña, M Salomón, L Torres and S Urbina (2003), "Mendoza y el uso del agua", in A Cirelli and E M Abraham (editors), El Agua en Iberoamérica: Aspectos de la Problemática de las Tierras Secas, CYTED, Subprograma XVII, Buenos Aires, pages 17-33.

UN DESA (2018), "World urbanization prospects: key facts", in World Urbanization Prospects 2018, United Nations Department of Economic and Social Affairs, Population Division, accessed 27 June 2019 at https://population.un.org/wpp/ Publications/Files/WUP2018-KeyFacts.pdf.

UN DESA (2019), World Population Prospects 2019: Highlights, No ST/ESA/SER.A/423, United Nations Department of Economic and Social Affairs, Population Division, accessed 27 June 2019 at https://population.un.org/wpp/Publications/ Files/WPP2019_Highlights.pdf. 


\section{ENVIRONMENT\& URBANIZATION}

UNICIPIO (2018), Plan de Acción Área Metropolitana de Mendoza Sostenible, Consejo de Coordinación de Políticas Públicas para el Área Metropolitana.

Vammen, K (2015), "A quick look: urban waters in the Americas", in Urban Water Challenges in the Americas: A Perspective from the Academies of Sciences, Inter-American Network of Academies of Sciences (IANAS) and United Nations Educational, Scientific and Cultural Organization (UNESCO), Paris and Montevideo.

Vásquez-Del Castillo, D A, M G Burboa-Zazueta, M A Valdés-Covarrubias, J Roberge, R Harris and L E Gutiérrez-Millán (2013), "Ingesta de arsénico de agua potable en la población de Hermosillo, Sonora", Revista de Ciencias Biológicas y de la Salud Vol XV, No 1, pages 39-44.

Villalba, R, M H Masiokas, $\mathrm{T}$ Kitzberger and $\mathrm{J}$ A Boninsegna (2005), "Biogeographical consequences of recent climate changes in the
Southern Andes of Argentina", in U M Huber, H K M Bugmann and M A Reasoner (editors), Global Change and Mountain Regions: An Overview of Current Knowledge, Springer Netherlands, Dordrecht, pages 157-166.

Whitten, G, M Hann, A Robles-Morua, A S Mayer and E R Vivoni (2014), "Enhancing the link between surface and groundwater models for climate change assessment of water supply and demand in Northwest Mexico", in iEMSs 2014 Proceedings, International Conference on Environmental Modelling and Software, San Diego, pages 1-8.

Zuniga-Teran, A A and C Staddon (2019), "Chapter 13: Tucson, Arizona - A story of "water resilience" through diversifying water sources, demand management, and ecosystem restoration", in P Juuti, H Mattile, R Rajala, K Schwartz and C Staddon (editors), Resilient Water Services and Systems: The Foundations of Well-Being, IWA Publishing. 